\title{
Community Policing and the Limits of the Bureaucratic State
}

\author{
Melissa Bull
}

ARC Centre of Excellence in Policing and Security, Griffith University, Mt Gravatt, QLD, 4122

Telephone: +61 737353328

Fax: + 61737351033

Email: m.bull@griffith.edu.au

Article Note:

\begin{abstract}
This paper explores contemporary challenges that community policing practices pose to unified understandings of sovereignty that traditionally underpin the delivery of state-centred policing in developed states. Fleming (2009) suggests that community policing is about partnerships, consultation and building trust in communities. Through a case study of the development of a local security network in an inner suburb of Melbourne (Victoria, Australia), I explore how state police work with other community agencies. Interviews with police and service providers identified past experience of policing in remote or international contexts, and an appreciation of community development principles, as factors that contribute to effective community policing. I discuss these claims, drawing on international policing literature that critically evaluates capacity building in a range of so called 'fragile' states, arguing that greater consideration of policing in differently organised states could reshape our understanding and expectations of community policing at home.
\end{abstract}

Keywords: community policing, international policing, capacity building, community development 


\section{Community Policing and the Limits of the Bureaucratic State}

\section{Introduction}

Community policing is a common term in contemporary policing forums. Although it is widely used, its meaning is not always clear. Noting the problem of definition Fleming (2009) suggests that most commentators agree that community policing is about partnerships, consultation and building trust in communities. It has been described - by professionals and scholars - as signaling a shift in policing styles from a model emphasising expertise and a centralised bureaucratic command structure, to an inclusive philosophy promoting community based problem solving strategies and encouraging partnerships between the police and communities in a collaborative effort to solve problems linked to crime and disorder. This generally involves significant changes in organisational philosophy, which are accompanied by a range of programmes and activities designed to reduce and prevent crime by increasing interaction and cooperation between local law enforcement agencies and the public. Such strategies aim to ameliorate community distress, fight crime and disorder and provide reassurance. Mackenzie and Henry (2009) provide a similar definition highlighting key characteristics including: decentralisation of responsibility within policing organisations, partnership with other agencies that take action when members of the public make demands that are beyond the operational scope of public police, community engagement, proactive problem solving and a shift in philosophy. They conclude, that community policing involves a changed understanding of 'real' police work that sees officers as 'peace officers' embedded in networks in their communities rather than simply, or only, reactive law enforcers (2009, p.4). Community policing, then involves decentralisation and proactive localised initiatives. It often works through a network of linkages between the police, various organisations and community members, rather than direct interaction between the police and the public.

The diverse range of operational contexts that support the implementation of community policing means that no one-size-fits-all. For example Skogan (2009) explains that community policing in the United States (US) is shaped by 
the features of its policing system which is decentralized, locally funded, localistic in leadership and culture and highly responsive to politicians. This contrasts with Australian jurisdictions, with centralised public policing agencies generally responsible for very large geographical areas, policing the diverse needs of capital cities, towns, rural settings and remote bush communities. This paper is focused on community policing as it is delivered in a particular Australian metropolitan context. Drawing on Fleming (2009) and Mackenzie and Henry (2009), in this paper the key characteristics of community policing are defined as decentralized and proactive localised initiatives, and the ability of police to become part of a web or network of partnerships across professional groups, public and voluntary sector agencies that work with communities to address common issues and problems associated with crime and safety.

In Australia the commitment of policing organisations to community policing has waxed and waned with changes in commissioners, command structures and governments. While often identified as a pillar of performance in strategic policy statements (Victoria Police 2008a), no jurisdiction has sought to restructure its policing organisation with a view to making community policing the dominant policing paradigm (Fleming and O’Reilly 2007). While it is an approach commonly adopted to address local crime and safety needs, Australian police organisations balance any engagement with the community against their commitment to corporate governance, performance management, accountability mechanisms and productivity (Fleming 2009). This works against any core focus on community policing, and as a result it is rarely taken into account in tasking and coordination at the local level. At the operational level reassurance policing, proactive engagement and the development of relationships with community agencies is often seen as not part of, or of value to, or relevant in the daily work of many officers (Bull 2010; Bayley 2001).

In contrast community policing skills are highly valued when it comes to policing activities in international forums. In Australia domestic police are often seconded to international policing missions because they have community policing experience (Harris and Goldsmith 2009), even though there is little research evidence suggesting that it is effectively deployed as a policing strategy in the local context (Bull 2010; Fleming 2009). Ironically there is some research suggesting that the transfer of experience might follow in the opposite direction: 
that international experience may enhance the local delivery of community policing (Goldsmith 2009; Dupont and Tanner 2008, 2009; Bull and Sinclair 2012).

This paper explores the relationship between international and domestic policing. It does so through a case study of community policing as an element of a local security network that was designed to address the crime and safety needs of newly arrived African populations, recently settled in a large public housing estate in Flemington, an inner suburb of Melbourne, Australia. The case study mapped police-community engagement through the development of partnerships across public, private and voluntary sectors in 2009-2010. It included interviews with police and community service providers, which explored factors that contributed to effective partnership and collaboration in local problem solving. Eighteen police across a range of ranks and roles and eighteen community service providers who formed a local service network across the fields of health, education, employment, settlement, housing and support were interviewed. Questions explored the factors that influence how well police work with community service providers to respond to the crime and safety needs of culturally diverse groups who are often difficult to reach. Ethics approval was provided through both Victoria Police (VPHREC76/09) and Swinburne University of Technology Human Research Ethics Committee (SUHREC project 2009/09). In this article police interviewees are referred to as P1 through to P18, and Community Services Providers as CSP1 through to CSP18 to maintain confidentiality.

Some police and community service providers described how deployment in international or remote Australian settings had shaped their professional practice, and how they engaged with community policing practices, or partnership and networked approaches for responding to local crime and safety needs, in the case study setting. This prompted me to review scholarship on international policing and service delivery in states defined as developing, weak, fragmented or disorganised (for example: Dinnen and McLeod 2009; Baker, 2008; Kyed 2009, Harris and Goldsmith 2009, Goldsmith 2009). I prefer to describe them as differently organised. In these states, for various reasons, policing is often much less state-centred and is frequently carried out in conjunction with non-state actors. Public police commonly work with, and rely on, other public, private and voluntary sector organisations when addressing local crime and safety needs. 
Taking this into account, I ask whether there is something to be learned about the new forms of policing in neo-liberal states from the experience of policing differently organized states. Drawing a conceptual link between literature describing policing in differently organised states and theoretical discussions of the challenges of policing in neo-liberal states, I argue that international exposure to policing in differently organized states provides experiences that can potentially shape, and enhance, the ability of domestic police to value working in partnership with other agencies in neo-liberal states where the objective of government bureaucracies is steering, rather than rowing (Crawford 2006), and there is a growing policy focus on preventive partnerships with the private and voluntary sectors (Garland 1996, 2001). In short, the question this paper explores is whether it is possible that international policing experiences can provide an opportunity for the two-way enhancement of policing, rather than simply the transfer of skill and knowledge from donor to recipient states. This calls for a more integrated understanding of the ways that policing crosses the international-local divide.

This paper begins with a brief overview of the Flemington case study that describes the social and institutional context of policing partnerships. This is followed by a summary of responses to questions exploring whom police and community services providers worked with and the factors - personal, professional and institutional - that facilitated the formation of partnerships and networked relationships and activities that addressed crime and safety problems in Flemington. The paper concludes by discussing these responses in the context of the international policing literature and theoretical frameworks referred to above.

\section{The case study}

Deploying community policing strategies in Flemington, which is a culturally and socio-economically diverse suburb, has been difficult. The opportunities for Victoria Police to work closely with the local community to identify security concerns, build trust, and target the causes of crime have been hampered by a documented history of tension (McCulloch 1996; Windle 2008; Hopkins 2007). In 2005 and 2006 media coverage of confrontational events linked to the Flemington public housing estate focused attention on a need to strengthen relationships between key stakeholders working and living in the area (Moonee Valley City Council 2009). This was highlighted during a State Government 
Community Cabinet in April 2008 by the community’s demand for stronger and more coordinated service provision. By June of that year a group of key service providers and government departments, including Victoria Police, had come together to plan the development of a community capacity building project. In September of 2007 the stakeholders, including community members, nongovernment service providers and government agencies agreed on a shared vision:

To work in partnership towards creating a positive community that is inclusive, welcoming and safe (Moonee Valley City Council 2009).

Victoria Police involvement in this project of community partnership and service coordination was consistent with strategic goals identified in that organisations key policy documents. "Connecting with the community” was identified in The Way Ahead 2008-2013 (then the overarching strategic vision) as one of three areas of organisational focus. Connecting with the community was specifically about engaging with partners in local government and local communities, which was identified as a strategy for working with young people at risk of becoming offenders, and for connecting with people from new and emerging communities who may feel disconnected in an unfamiliar environment. The Multicultural Policy Statement 2007: Proud to be working in partnerships with culturally and linguistically diverse communities (Victoria Police 2007) explained that the best way to achieve community safety is working "in partnership with government agencies and service providers, community groups of all faiths and backgrounds, and the private sector” (Victoria Police 2007, 3). Victoria Police Multi-faith Action Plan (2008c, 4) marked a commitment to "working in partnership with all community groups at the proactive level”, identifying the development of linkages at the local level as one of the best ways to enhance community confidence, build effective resilient networks, and further strengthen pathways for information exchange.

Despite this institutional commitment to partnerships and networked approaches, interviews with police who had worked in the Flemington setting indicated that, reassurance policing, proactive engagement, and the development of relationships with the community often was not seen as part of, or relevant to, the daily work of many officers. This was particularly the case for those working 
in criminal investigations units, but it was also a view expressed by some whose work involved general duties. It was not "real policing”, but rather a soft option [P6, P15]. Admittedly a number of police personnel interviewed described how in the course of their career they had come to appreciate the value of what they called the "softly softly" approach and taking a longer term view in achieving a particular outcome [P7, P17]. Nevertheless, according to most, working with the community to proactively build relationships, implement programs and develop networks took resources - vehicles, personnel and time - away from "real policing” [P5, P6, P7, P9, P10, P11, P15]. Those deployed in such activities would be of more use on patrol in the van, or assisting with administrative roles. Community policing was not perceived as constituting a useful resource for all. For some it was “just PR" [P6]. A few members [P7, P16, P17] however, saw the formation of relationships with the community and with other service providers as a way of making their job easier: by knowing who to go to when problems arose, or by knowing who to refer to thereby freeing themselves for other police work, or by being able to avert a situation by being able to "nip it in the bud" ([P17], McGarrell 2004). More often, however, officers failed to value relationships as a resource that could be used to leverage other resources or services.

A miss-match in management structures between the centralised and local levels had the effect of limiting the translation of policy principles like "Connecting with the community", and even the more operationally focused Multicultural Action Plan (Victoria Police 2008b) and its regional derivatives into daily policing operations. Centralised bureaucratic processes and administrative systems conflicted with devolved management practices that support community policing (p. 1 above), which valued rank and file autonomy at the police service level. For example, the complexity of centrally managed procurement procedures hindered timely delivery of programs and responses. These processes and systems were seen to thwart flexibility and spontaneity so often needed in sensitive moments of diplomacy and negotiation involved in building relationships with groups that are difficult for police to reach [P16]. Alternatively, autonomy in some contexts allowed rank and file members to simply ignore higher level strategic planning that valued the development of networks of relationships. A number of those interviewed indicated that they only took account of such approaches to policing in so far as engaging in partnership or relationship building 
activities "ticked the box" and "looks good in an application for promotion" [P5, P6, P10]. This was evident through the variation in priority and recognition allocated to community policing opportunities in tasking and coordination activities across management or police service units. At the time of this study, assurance styles of policing were not a consideration at Tasking and Coordination meetings that allocated the workload for Flemington policing personnel [P9, P10].

When compared to the partnerships identified by the community sector in interviews, the number and profile of the organisations that police personnel worked with to promote community safety and address local crime issues were similar in relation to engagement with educational and vocational institutions, youth services, commercial interests and “other agencies”. Similarities were also apparent in relation to involvement with non-police criminal justice agencies. Here police and community service agencies commonly identified: community legal services, legal aid and court support services as partners in service delivery. In contrast, police mentioned fewer connections to the media, community welfare organisations (2 compared to 12), migrant services and support groups (12 compared to 17), and coordinated service delivery networks. They described greater engagement with sporting organisations, health services and other government departments.

Compared to non-police organisations, police worked much more extensively with government departments identifying more than twice as many connections, and these were much more inwardly focused. Nearly two thirds of the thirty government partners police collectively identified were police and emergency services agencies. Half of these were Victoria Police members from their own Police Service Area (PSA). Greater contact with health services was a reflection of both the role played by police in family violence liaison, as well as that played in the management of those with mental health issues (Department of Health (Victoria) 2010) [P8]. Links to sporting organisations were a reflection of police norms when it comes to community engagement. Harvey et al. (2010) explain that in Australia police commonly use sport and recreation programs as a means of engaging with young people from marginalised groups.

Another notable difference between police and community sector personnel was the focused nature of engagement. In the community sector, most interviewees were embedded in complex networks of information exchange and 
service delivery. For the Victoria Police, the network of local connections described were largely concentrated around 10 of 18 personnel interviewed. They mainly reflected the relationships developed and maintained by 6 dedicated liaison officers and 3 others with managerial roles. For the remainder of the officers, engagement with partnership policing was much more limited. Those with less extensive networks variously explained that they didn't really have networks, 'not outside of the service' as their work had a narrow focus on dealing with crime, building relationships was "not part of the[ir] role", they "go to the YRO (youth resource officer), MLO (multicultural liaison officer) or the Boss (Inspector or Senior Sergeant)” and there wasn't “an opportunity for a two way thing” with members of the community and community service agencies [P5, P6, P15]. One member who had limited community networks thoughtfully acknowledged that it was a "matter of frequency of engagement" - "time spent working with others... was much more limited” [P7].

Interviews with police members explored institutional and personal factors that supported them to work in partnership with others - including community groups and community service agencies - in responding to the needs of those from diverse backgrounds. Most confidently stated that at the institutional level there were no formal standard operating procedures to assist them in this regard. Three felt there may be guidelines they were unaware of, and two said that guidelines existed. When personnel were asked specifically about the Regional Multicultural Plan, five of those interviewed knew of it, and two had read it. These two were MLOs, the remaining three were in more senior managerial roles.

At the personal level experience was important. This included past working experiences in the police service: the length of time "working on the job”, working in diverse [regional] areas with diverse [Indigenous] populations, undercover experience which helped members to understand different backgrounds and points of view, and having good networks at work [P2]. Past working experience in other jobs: familiarity with emergency services, overseas deployment in different countries, awareness of and understanding of mental illness, and having good [work] networks more generally were also said to help police to develop an "appreciation of the bigger picture”, or “a longer view”, "patience” and "flexibility" [P7, P14]. 
Analysis suggests that the experience of working in an environment without backup through the benefit of other police, or the taken for grant services of a centralised bureaucratic state, helped police think about how to do their job differently and appreciate the value of other non-government service providers that they might work with and rely on. One officer explained, for example, that a posting to a regional area that involved working in isolated Indigenous communities meant that they were:

“often alone, with no other services or back up”, this meant that they had to “develop strategies to manage isolation and these helped to develop initiative, making [you] more self-sufficient and resourceful”.

The same officer also suggested that being undercover was "like being in a foreign country" and this "got you to see things differently, and that there might be different solutions” [P2]. The idea that international deployment was beneficial was explicitly addressed by another officer who responded when asked "what specific skills or knowledge obtained in previous jobs has most assisted you in your current role?” that:

“experience in different countries helps you to view things differently”...

“"acknowledge the work of others who played a greater role” and avoid being "too focused on VicPol” [P14].

Interviews with community service providers also explored institutional and personal factors that supported police to work in partnership with others when responding to the needs of those from diverse backgrounds. Service providers demonstrated an appreciation of the challenges faced by police, but commonly described uneven relations with Victoria Police and police from the local PSA in particular. Community service providers identified a lack of continuity in personnel ("not knowing who to go to"), the failure of police to provide handover when there were changes in personnel, and the tendency of police not to come to meetings, or to acknowledge the work of others, as factors that undermined the 
development of coordinated service delivery that included the police. Some service providers explained that different types of knowledge supported collaboration and the formation of partnerships. Sometimes this was formally acquired knowledge like a background in social science, sociology, anthropology, community development/capacity building or technical knowledge including project management, research skills (for gathering and evaluating information) and information technology skills. Participants also identified knowledge of the African community, or other culturally and linguistically diverse communities, and the differences in approach to everyday life, or an understanding of how communities work, as important.

At the operational level community service providers said that individual police needed better understanding of the agencies around the table and the types of work that they do. This includes: understanding community agencies, understanding service sector specific issues and the work systems of community agencies.

“They need to recognise and give credit to the initiatives of other agencies, acknowledging the role they may have in broader programs' ...[CSP7, CSP17].

A number of the interviewees from this sector had their own experiences of international missions (in Timor Leste for example) and/or had been involved with community development work in remote settings in Central Australia or the Northern Territory of Australia (CSP5, CSP6, CSP9). They highlighted the importance of community development and engagement as effective approaches for building partnerships and networks, i.e. for community policing. CSP5, who had worked in remote areas of the Northern Territory ${ }^{1}$ explained this assisted because it provided an experience that was 'less reductive, or Western,' ... 'it required a logical approach that was outward looking'... 'relied on connections and relationships' ... 'looking to opportunities and looking to strengths, the opposite of the deficit approach often adopted by police'. Most suggested that for police to be effective they needed to have a commitment to community capacity

\footnotetext{
${ }^{1}$ Areas where the standards of basic infrastructure and the spectrum of services in relation to housing, health, education, employment and welfare, generally taken for granted in developed democratic states are largely absent.
} 
building and community development, they should be "more like community development workers” (CSP5).

\section{Discussion}

The analysis above describes some of the challenges faced in relation to the delivery of community policing in terms of building partnerships and wholeof-government responses to crime and safety issues that include policing (Fleming 2009 above p.1). Community policing and the development of partnerships and relationship building within the community to identify and solve problems was not valued by most of the police personnel who were interviewed. It was seen as not real policing and to sap valuable resources. One middle manager saw it as valuable, not only as a means of building trust and confidence in a community that had poor relationships with police, but and as a means to leverage resources (a way of making his limited resources go further). The delivery of community policing was thwarted by centralised bureaucratic processes that conflicted with the devolved local nature of decision-making and engagement characteristic of community policing. In comparison to the community service providers interviewed as part of this project, the relationships and networks described by police were inwardly focused on other police and emergency services. They did include other government departments responsible for education, vocational and sports, legal services, court support and health services. Police identified experience - including offshore experience and experience in remote settings, both settings where community development would be deployed — as a factor that assisted them to build partnerships that helped them to work with the community. This was complimented by the suggestion from community service providers that police would benefit from a better appreciation of community development approaches. A number of these community service providers had worked overseas and in remote locations. Historically tertiary training in community development has been preparation for international aid and development work. The interviews conducted as part of this study demonstrated that such training has increasing relevance for working with newly arrived communities in the domestic context.

According to Harris and Goldsmith (2009) domestic experience of community policing is said to be valued when it comes to Australian deployments 
in international settings. Nevertheless, scholarly work on this aspect of international policing is often critical. Dinnen and McLeod (2009), for example, are critical of deployment that they describe as reinforcing a state-centric view of policing and neglecting the contribution of other providers of policing services (a similar criticism that was made of police in Flemington CSP7, CSP17 p.10 above). They explain how local stakeholders, in recipient countries, repeatedly call for better linkages between the work of international policing missions with the state justice system and the informal efforts of local leaders and other nonstate actors to reconcile former adversaries and heal communities divided by conflict (Dinnen and McLeod 2009, 342).

Their argument is developed through an analysis of Melanesian environments, which are characterised by high levels of legal pluralism with a multiplicity of providers, of what might be broadly conceived as policing services: "any organised activity, whether by state or non-state groups, that seeks to ensure the maintenance of communal order, security and peace through elements of prevention, deterrence, investigation of breaches and punishment” (Baker 2008, 3).

Dinnen and McLeod (2009) explain that for most citizens who live in these environments everyday security is managed informally through resorting to local non-state mechanisms that have been adapting continuously to change. The idea of a state monopoly over security stands in marked contrast to the complex reality of regulatory pluralism found in the Melanesian contexts that were the subject of their work. Unlike the model of government associated with functioning statecentred societies, where designated authorities are largely responsible for maintaining social order within a given territory, non-state authority and social control in Melanesia are typically fluid, widely dispersed and actively contested. Contemporary social ordering in Melanesia is varied and complex, comprising multiple overlapping notions of order that derive authority and legitimacy from diverse sources including, for example, the modern state, tradition, Christianity and commercial enterprise. Citizens can engage in "forum shopping” when it comes managing conflict and disputes, choosing pragmatically according to their particular circumstances and needs (Dinnen and McLeod 2009, 336).

Bruce Baker is similarly critical in his assessment of the development of state-centred models of policing in Africa (Baker 2004a, 2004b, 2005a, 2005b). 
He explains that despite vain efforts for more than half a century to establish western models of policing, they have not successfully taken root. He acknowledges that this could be the result of many factors: under funding; endemic corruption amongst those who are associated with the state and possess the means of coercion; colonial origins of the police and decades of military rule that together produced militarised police forces that acted as instruments of oppression on behalf of the government; low state legitimacy; and widespread armed conflicts. Whatever the explanation, the state police are in effect absent from the scene as far as many Africans are concerned (Baker 2006).

Baker $(2006,2)$ concludes that "the inability of the police by themselves to provide security within that county created a security vacuum”, and as a consequence an array of policing agencies has arisen to fill the gaps. He argues that when security is considered from the point of view of the citizen "...the fluidity of policing becomes very apparent”, people are rarely users of either or private or public policing. Policing as it is experienced is a complex pattern of over lapping policing agencies, with citizens (like those referred to in Dinnen and McLeod's (2009) study) “shopping around” for their security needs. "Policing ... is provided by a surprising number of policing agencies offering localised protection of different levels of legality, effectiveness, availability, methods and services” (Baker 2006, 3). These agencies provide what Baker terms multi-choice policing (2004a, 2004c, 2005a, 2005b).

In this context the choice available in policing is not simply one between accountable public policing and minimally accountable private policing (Baker 2006). The choices for Africans are shaped by what is available, what works best, and what they can afford. Policing other than that provided by the state, however, is not necessarily policing that is autonomously delivered by other agents. The fragmentation of policing does not necessarily resemble the forms of diversification described as policing "away from” and "beyond” the state (Bayley and Shearing 2001; Loader 2000, 328). Baker (2006) avoids suggesting a straightforward state-non-state divide; he lists the range of strategies that states use to shape and influence policing agencies other than the state police. They include: "sponsorship, regulation/criminalisation, networking/exclusion, incorporation and training; ... all techniques by which the state may maintain a 
level of control over ostensibly non-state policing, and seeks to uphold its sovereignty” (Baker 2006, 3).

Baker describes the delivery of policing in terms of a fragmented sovereignty that does not have guaranteed permanence: it is contested and fragile. He concludes that this fragmented sovereignty belies any claim that national security strategies can be developed, and given a little more external aid the state police alone will shortly be able to provide universal protection. The states he studies are not in a position to offer security, law and order and crime control for all its citizens without turning to other policing providers for help. Such states can strengthen their sovereignty not by insisting on a monopoly on security and criminalising other security providers. Adopting a less ambitious definition of sovereignty that "concedes that the state is not the only (or even primary) provider of crime control ... is at least sustainable” (Baker 2006:14).

In this discussion I want to draw attention to conceptual similarities between the policing contexts described by Dinnen \& McLeod (2009), and Bruce Baker (2004a, 2004b, 2005a, 2005b, 2006, 2008, see also Hughes et al 2013) and those I found in Flemington. At the same time I acknowledge that there are important social, political and historical differences (which are usually the focus of analysis). The contexts described by the authors above are characterised by high levels of legal pluralism with a multiplicity of providers of what might be broadly conceived as policing services: “any organised activity, whether by state or non-state groups, that seeks to ensure the maintenance of communal order, security and peace through elements of prevention, deterrence, investigation of breaches and punishment” (Baker 2008, 3). Social ordering is varied and complex comprising multiple overlapping notions of order that derive authority and legitimacy from diverse sources: the modern state, tradition, religion, commercial interest (the market); with citizens shopping around pragmatically choosing the style of solution that is most likely to meet their needs.

The Flemington project involved the development of what could be described as a complex local security network. It consisted of a group of key stakeholders, which included Victoria Police as just one agency among other service providers, government departments, non-government organisations (NGOs), private operators and community groups. These agencies and 
organisations came together to plan the development of a community capacity building project. In September of 2007 they agreed on a shared vision:

To work in partnership towards creating a positive community that is inclusive, welcoming and safe (Moonee Valley City Council 2009).

Police were to work in partnership with a range of stakeholders from civil society: health, education, employment, housing, settlement, and welfare support, who crossed government, commercial and non-government domains, representing State and traditional (religious) authorities, commercial interests and voluntary associations; to respond to local community safety issues through coordinated service delivery.

This is potentially unremarkable. I am not the first to note the fragmentation of policing in developed western states. In 2001 Bayley and Shearing described how such fragmentation involved: the (re)entry of citizens into policing functions; non-governmental groups taking on responsibility for their own protection, and a variety of non-governmental agencies along with the private sector providing security services. Loader (2000), (see also Newburn 2001; Kemper, Carrier, Wood and Shearing 1999) proposed that the boundaries between state and non-state institutions (commercial, NGO and informal security) were not simply blurred but had been transformed by new cooperative networks. What is new here is the value of recognizing the conceptual link I draw between the limits of the sovereign state in developed neo-liberal settings and in differently organised states.

In 1996 David Garland notably pointed to the limits of state-centred models of policing in neo-liberal states. He described how towards the end of the twentieth century there was a withdrawal of the claim that the state alone could win the war against crime, along with the erosion of the foundational myth that the sovereign state is capable of providing security, law and order and crime control within its territorial boundaries. As a result the assertion that the state is the primary and effective provider of security and crime control has been qualified. Admitting these limits allows us to conceptually align the disorganisation of Garland's late modern state with Baker's developing states where police "by themselves" are unable to provide security: states that are not in a position to offer security, law and order and crime control for all citizens without turning to other policing providers for help (p. 14 above). Sustaining this 
comparison, Garland goes on to explain that the qualification of the state's monopolising tendencies provided the conditions of possibility for the introduction of 'new' techniques of policing and crime control that are addressed beyond the state; "that aim to embed controls in the fabric of normal interaction, rather than suspended from above through sovereign command” (Garland 1996, 451). These new approaches no longer take the state and its agencies to be the primary actors in the business of policing and crime control. Central government seeks to act upon crime not in a direct fashion through state agencies (police etc.) but instead by indirectly, seeking action on the part of non-state agencies and organisations. Crime prevention, inter-agency cooperation, multi-agency approaches, activating communities, and creating active citizens are key concepts in this devolved approach to policing.

Garland (1996) cautions (as do Rose and Miller 1992) that one should not underestimate the difficulty of getting these new forms of government-at-adistance to work. Likely problems include: the unevenness of non-state security: disparities in social provision and distribution of security; and difficulties of overcoming long established habits of thought - nurtured by state agencies in an earlier, monopolising phase - which counsel that "problems of disorder and deviance are best left to specialists and the appropriate authorities” (Garland 1996, 463). He explains that the state is not good at acting at a distance; indeed, it is not always effective in implementing policies through its own agencies. Governments have not been intent upon devolving power or creating the kind of associational democracy that might make these policies feasible. Instead they have tended to combine moves for the devolution of policing with means intended to consolidate central power. These tensions were evident in Flemington.

\section{The unevenness of state and non-state security:}

Geographical and jurisdiction boundaries for police service areas, state or local government areas, along with those boundaries shaping the reach of nongovernment services provided opportunities for discontinuity and uneven policing responses and service delivery (Jacobs et al. 2007). The housing estate that was the focus of this study was situated close to and across these types of boundaries. Its proximity to the jurisdictional boundary for the PSA covering Melbourne CBD 
meant that police personnel from the local Flemington station were often deployed to city disturbances. This frequently left the area underserviced with personnel from neighbouring PSAs (North Melbourne, Ascot Vale) temporarily filling the gaps. Police responses from personnel that came from outside the area where identified as interrupting the continuity of service: "they [were] not consistent with local responses and [were] too high handed” [CSP4]. Residents also complained about the impact of changes to local government boundaries which positioned Flemington in the City of Moonee Valley Local Government Area rather than Melbourne City Local Government Area. This was experienced as a loss of amenity, of access to effective voice through local government representation and an associated loss of services. There was a sense that the area fell in a gap. In addition, physical geographical barriers - a particularly large freeway intersecting with a rail corridor - created empty public space that impacted negatively on the visual amenity and safety of the area, while acting as a practical barrier to seemingly local service delivery on the other side of the tracks. Community members, whether victims or offenders, were often unaware of, and unlikely to modify behaviour according to, such boundaries. They were confused when they received different treatment from operational police units and other service providers from neighbouring areas, governed by different managers and directives, policing across boundaries when workloads were high. Ignorant of, or uninterested in, matters of territorial and organisational demarcation and management, community members living close to or on these boundaries (as the housing estate residents were) perceived their variable access to and delivery of services as evidence of bias or inequitable service delivery (Bull and Meredyth 2012).

The difficulties of overcoming long established habits of thought:

Police attitudes and viewpoints, resource allocation and leadership play an important role in establishing, maintaining and continuing partnerships (Jacobs et al. 2007). The nature of resource allocation (e.g. the failure to take community policing and relationship building activities into account in Tasking and Coordination meetings) along with the attitudes and viewpoints of many of the police interviewed as part of this study confirmed an approach to policing that 
presumes that problems of disorder and deviance are best left to the appropriate authorities (i.e. the police). Many of the operational police in this study did not have a strong commitment to partnership activities, seeing it as not relevant to their work. Consistent with reported research (Liederback et al. 2007), they assigned a greater importance to traditional crime problems and privileged traditional law enforcement practices as the most appropriate response to security and safety in the community. The dominance of command and control policing structures tended to limit the possibilities for community policing initiatives (Somerville 2009). This was exemplified in the inwardly focused partnerships and networks of the police (together with their generally poor connection with, and understanding of, the roles of services providers) and their tendency to rely on only a few dedicated police personnel when it came to working with the community.

The devolution of policing and the centralisation of power:

Centralised bureaucratic processes and administrative systems conflicted with devolved management practices, which valued rank and file autonomy at the police service level. For example, the complexity of centrally managed procurement procedures hindered timely delivery of programs and responses. At the local level in Flemington relationship building was left to very few members: those in middle management roles - inspectors in charge of the PSA, senior sergeants - and some more junior constables and senior constables in dedicated liaison officer roles. These ranks and roles worked autonomously with service providers and members of the community. Community agency interviewees described how good relationships and levels of understanding could be developed with liaison officers and some managers. This however led to a differentiation not only between this role, but this "person” as a "good” cop, and the rest of the police service as "bad" cops. This limited the value of the relationships built, the maintenance of relationships when personnel changed, and the development of future relationships. It also diminished any opportunity for the transfer of skills and knowledge between personnel or broader organisational change.

Despite these challenges a small number of police effectively worked with others and built positive relationships with the community and service providers. 
These police had extensive networks and a comprehensive understanding of the social context that they worked within. Amongst these police were personnel who engaged with the community in ways that leveraged the resources they had available to them (outsourcing roles that might have been performed reluctantly by police). This led me to wonder what helped these police to adapt to working in what Garland (1996, 2001) describes as the disorganised conditions of late modernity? Is there, as some police personnel and community service providers suggest, something to be learned from policing in remote settings, or international settings; settings where development approaches to community capacity building are often mobilised? Do states that have been described as disorganised, fragmented, weak or vulnerable - states that are differently organised - have important policing stories to tell? In short, does the experience of policing in situations where the standards of basic infrastructure and the spectrum of services in relation to housing, health, education, employment and welfare, generally taken for granted in developed democratic states, are largely absent, help police to form and value relationships and partnerships that aid community policing (as defined above)? And does this impact in positive ways on their professional practice in their home setting?

Hansen and Stepputat (2006) explain that the types of states I refer to as differently organised have a long history of fragmented sovereignty; and even in colonial /post colonial contexts, the state has never claimed a monopoly on the everyday use of force or crime control. Policing delivered in the context of a functioning centralised bureaucratic state is not the dominant model. In the Flemington example the delivery of community policing, involving a shift from models of policing emphasising expertise and centralised bureaucratic command structures to more inclusive models promoting community based problem solving strategies and encouraging partnership between policing and communities, proved problematic for all but a few. Those police and community service providers who were successful in building partnerships had diverse experiences, including experience of policing in remote and international settings. This raises the possibility that the capacity exchange that accrues to police who have served in these contexts has its roots not only in professional exchanges of knowledge and skill (Harris and Goldsmith 2009; Dupont and Tanner 2008, 2009; Bull and Sinclair 2012, in press), but in the very disorganisation - or different organisation 
- of so called weak states. This suggests that there is something to be learned in relation to responding to the fragmentation of policing in the neo-liberal states from the experience of policing in states often described as disorganised, fragile or weak. Viewing them as differently organised rather that insisting that they conform to Western models of government addresses the criticisms of Dinnen and McLeod (2009) and Baker (2006) described above. Furthermore, it opens the possibility, that policing in these states should not be measured against the yardstick of the Weberian state, and that such states should be recognised as differently organised with their own genealogies of weaknesses and strength. This is important because it shifts attention from deficit models of international policing (Allen and Dinnen 2010) that focus only on fixing what's wrong (policing problems) in deployment sites, to acknowledging and perhaps learning from innovative forms of policing that may have developed there. I am not arguing that models of policing evident in differently organised states should be adopted in neo-liberal policing environments like Australia, but that the professional practice of individual police might benefit from deployment experiences. Working in environments where the expected infrastructure of state cannot be taken for granted may challenge 'long established habits of thought' and practice, and inspire new habits of collaboration and innovation that benefit the delivery of community policing in Australia.

\section{Conclusion}

This article has described the difficulties of deploying community policing strategies to ameliorate community distress, crime and disorder and provide reassurance to newly arrived African people living in a public housing estate in Flemington, located four kilometres from the CBD of Melbourne. These strategies were associated with the Flemington project and involved activities designed to reduce and prevent crime by increasing interaction and cooperation between local law enforcement agencies and other local and state government agencies, the private sector, NGOs and community groups. Some police and other service providers described how deployment in international or remote Australian settings had shaped their professional practice - it helped them to engage with community 
policing practices, or partnership and networked approaches to community policing in the case study setting.

By highlighting conceptual similarities - i.e. the limits of state-centred policing and the fragmentation of sovereignty in states commonly described as weak or fragile and neo-liberal states - I turn the common understanding of the relationship between domestic and international policing on its head. Seeing weak states as differently organised, rather than disorganised, allows us to rethink the nature of the policing exchange between developed and developing states. It is short sighted to evaluate policing in developing states strictly in terms of the demands of a state-centred model of policing that is struggling to meet the governmental demands of a neo-liberal state. Doing so has the effect of deflecting attention from lessons that might be learned from innovative and adaptive forms of policing that can occur in those settings. Taking the analysis above into account this might include practical strategies that help police (and other service providers) to respond better to the needs of newly arrived populations from differently organised states; or to adapt to the different forms organisation associated with what Garland referred to as the disorganisation of the changing conditions of late modernity. At a more abstract level, this paper also raises questions in relation to conventional understandings of the delivery of community policing expertise in the context of international policing and domestic policing settings, and the conceptual relationship between the two. In relation to domestic policing it potentially challenges the value of maintaining a dedicated standing capacity for international deployment, suggesting there might be local benefits for state policing agencies that adopt a strategic approach interchanging deployment of personnel internationally and domestically in order to enhance their skills and capacity for innovation.

\section{References:}

Allen, M. \& Dinnen, S. (2010) 'The North down under: Antinomies of conflict and intervention in Solomon Islands', Conflict, Security and Development, 19(3), 299-327.

Baker, B. (2004a). Protection from crime: What is on offer for Africans? Journal of Contemporary African Studies, 22(2), 165-188. 
Baker, B. (2004b). Multi-choice Policing in Africa: is the Continent Following the South African pattern? Society in Transition, 35(2), 204-223.

Baker, B. (2005a). Multi-choice Policing in Uganda. Policing and Society: An International Journal of Research and Policy, 15(1), 19-41.

Baker, B. (2005b). Who do People Turn to for Policing in Sierra Leone? Journal of Contemporary African Studies, 23(3), 371-390.

Baker, B. (2006). Beyond the State Police in Urban Uganda and Sierra Leone. Afrika Spectrum, 41(1), 55-76.

Baker, B (2008). Multi-choice policing in Africa. Uppsala: Nordiska Afrikaniansituter.

Bayley, D. (1994). Police for the Future. Oxford: OUP.

Bayley, D. (2001). Democratizing the police abroad: What to do and how to do it. Washington, DC: National Institute of Justice.

Baley, D \& Shearing, C (2001). The New Structure of Policing: Description, Conceptualisation and Research Agenda. Washington, U.S: Department of Justice, Office of Justice Programs, National Institute of Justice.

Brogden, M. \& Nijhar, P. (2005). Community Policing: National and International Models and Approaches. Devon: Willan Publishing.

Bull, M. (2010). Working with others to build cooperation, confidence and trust, Policing: A Journal of Policy and Practice, Special Issue, 4(3), 282-290.

Bull, M., \& Meredyth, D. (2012). Exploring the experience of security in multiethnic communities undergoing rapid change: A Flemington case study. Brisbane: ARC Centre of Excellence in Policing and Security, Griffith University, and Institute of Social Research, Swinburne University of Technology.

Bull, M. \& Sinclair, G. (2012). ) 'Keeping the peace at home: the exchange of capacity in international and local policing forums', paper presented at British Society of Criminology Conference, Portsmouth, UK, July 3-7.

Crawford, A. (2006). Networked governance and the post-regulatory state? Steering, rowing and anchoring the provision of policing and security. Theoretical Criminology, 10(4), 449-479.

Department of Health (Victoria) (2010) Department of Health and Victoria Police Protocol for Mental Health, Mental Health and Drugs Division, Victorian Government. 
http://www.health.vic.gov.au/mentalhealth/publications/police-mhprotocol0910.pdf, accessed 10 July 2011.

Dinnen, S. \& McLeod, A (2009) Policing Melanesia - international expectations and local realities. Policing and Society: An International Journal of Research and Policy, 19(4), 333-353.

Dupont, B., \& Tanner, S., (2008). What Happens Before and After: The Organisational and Human Resources Challenges of Deploying Canadian Police Peacekeepers Abroad. Montreal, Canada: International Centre for Comparative Criminology, University of Montreal.

Dupont, B., \& Tanner, S. (2009). Not always a happy ending: Organisational challenges of deploying and re-integrating civilian police peacekeepers (a Canadian perspective). Policing and Society, 19(2), 134-146.

Fleming, J. (2009) Community Policing, in A.Wakefield \& J. Fleming, (Eds.), The Sage Dictionary of Policing (pp. 37-39). Sage: London

Fleming, J. \& O'Reilly, J. (2008). In search of a process: community policing in Australia. In T. Williamson (Ed.) The Handbook of Knowledge-Based Policing: Current Concepts and Future Directions (pp. 139-156). Sussex: John Wiley \& Sons.

Garland, D. (1996). The Limits of the Sovereign State: Strategies of Crime Control in Contemporary Society. British Journal of Criminology, 36(4), 445-471.

Goldsmith, A. (2009). It Wasn't Like Normal Policing: Voices of Australian Police Peace-Keepers in Operation Serene, Timor 2006. Policing and Society, 19(2), 119-133.

Hansen, T. \& Stepputat F. (2006). Sovereignty Revisited, Annual Review of Anthropology, 35:295-315.

Harris, V. \& Goldsmith, A. (2009). International Police Missions as Reverse Capacity Building: Experiences of Australian Police Personnel. Policing: A Journal of Policy and Practice, 3(1), 50-58.

Harvey, R., Hogg, R., \& Bull, M. (2010). Working with Muslim communities in Australia: a review of the Community Policing Partnership Project'. Canberra: Australian Human Rights Commission and the Australian Multicultural Foundation.

Hopkins , T. (2007). Complaints Against Police Behaviour in Flemington, 
Victoria, 2006. Alternative Law Journal, 32(1), 32-36.

Hughes, B., Hunt, C. T., \& Curth-Bibb, J. (2013). Forging New Conventional

Wisdom Beyond International Policing: Learning from Complex Political Realities. Leiden, Netherlands: Martinus Nijhoff Publishers.

Jacobs, K., Burke, T., Green, M., Saggers, S., Mason, R., \& Barclay, A. (2007).

Making sense of partnerships: a study of police and housing department collaboration for tackling drug and related problems on public housing estates (NDLERF Monograph Series No. 26). Hobart, Tasmania: National Drug Law Enforcement Research Fund.

Johnston, L. (2003). From 'pluralisation' to the 'the police extended family': discourses on the governance of community policing in Britain'. International Journal of the Sociology of Law, 31 (3), 185-204.

Kyed, H. M. (2009). Community policing in post-war Mozambique. Policing \& Society, 19(4), 354-371.

Liederback , J. Fritsch, E., Carter, D., \& Bannister, A. (2007). Exploring the limits of collaboration in community policing: A direct comparison of police and citizen views. Policing: An International Journal of Police Strategies \& Management, 31(2), 271-291.

Kempa, M., Carrier, R., Wood, J \& Shearing, C. (1999) Reflections of the Evolving Concept of 'Private Policing', European Journal on Criminal Policy and Research, 7(2), 197-223.

Loader, I. (2000). Plural policing and democratic governance. Social \& Legal Studies, 9(3), 323-45.

Manning, P. (1984). Community Policing. American Journal of Police, 3(2), 305228.

McCulloch, J. (1996). Blue Murder: Press Coverage of Fatal Police Shootings in Victoria. Australian \& New Zealand Journal of Criminology, 29(2), 102120.

Moonee Valley City Council (2009) What is the Flemington Project? Moonee Valley City Council.

Newburn, T. (2001). The Commodification of Policing: Security Networks in the Late Modern City. Urban Studies, 38(5), 829-48

MacKenzie, S. \& Henry, A. (2009). Community Policing: A Review of the 
Evidence, Scottish Government Social Research, Edinburgh, www.scotland.gov.uk/socialresearch, accessed 10 December 2013.

Skogan, W. (2009) United States, in A. Wakefield \& J. Fleming, (Eds.), The Sage Dictionary of Policing (pp. 37-39). Sage: London

Somerville, P. (2009). Understanding community policing. Policing: An International Journal of Police Strategies \& Management, 32(2), 261-277.

Tilley, N. (2008). The Development of Community Policing in England:

Networks, Knowledge and Neighbourhoods. In T. Williamson (Ed.), The Handbook of Knowledge-Based Policing: Current Conceptions and Future Directions (pp. 95-116). Sussex: John Wiley \& Sons.

Victoria Police. (2007). Multicultural Policy Statement 2007: Proud to be working in partnerships with culturally and linguistically diverse communities. Melbourne: Author.

Victoria Police. (2008a). The Way Ahead: 2008-2013, Melbourne.

Victoria Police. (2008b). Multicultural Action Plan: Working in Partnership. Melbourne: Author.

Victoria Police. (2008c). Multifaith Action Plan: Working in Partnership with all Community Groups. Melbourne: Multicultural Advisory Unity, Operations Coordination Department, Victoria Police.

Windle, J. (2008). The racialisation of African youth in Australia. Social Identities, 14(5), 533-566.

Weber, M. (1919). Politics as Vocation. Lecture given at Munich University, 1918. http://www.mdx.ac.uk/www/study/xweb.htm, accessed 10 December 2013. 